\title{
PERBEDAAN KEMATANGAN SOSIAL ANAK USIA DINI DITINJAU DARI KEIKUTSERTAAN DI TAMAN PENITIPAN ANAK (TPA)
}

\author{
Adinni Vibrananda Lisardika \\ Fakultas Psikologi Universitas Kristen Satya Wacana \\ Email: adinvibra@gmail.com \\ Heru Astikasari Setya Murti \\ Fakultas Psikologi Universitas Kristen Satya Wacana \\ Email: heru.astika@gmail.com
}

\begin{abstract}
This research aims to know the defferent between social maturity early childhood In terms of participation in Children Day-Care. Sample in this research 60 subject consisting of 30 kids the age of 2 - 6 years charity at Children Day-Care and 30 kids the age of 2 - 6 years who do not charity at Children Day-Care. Technique the sample used in this research was sampling purposive. A measuring instrument used in this research was vineland social of maturity scale (VSMS). This research in analysis by using test $t$ (t-test) and obtained value of 10,037 uji-t and shows that significance obtained 0,000 $(p<0,001)$.The results of this means that there is a significant difference between ripeness child social is 1,093 and those who did not were entrusted in Children DayCare.Most of the dependants were in the landfill is considered to be in the category of ripeness of high social with rerata 108,3, while the majority of children who are not sent to the landfill was ripeness into the category of a social enough with rerata 82,18.
\end{abstract}

Keyword : Social Maturity, Childhood, Children Day-Care

\begin{abstract}
ABSTRAK
Penelitian ini bertujuan untuk mengetahui perbedaan kematangan sosial anak usia dini ditinjau dari keikutsertaan di Taman Penitipan Anak (TPA). Sampel dalam penelitian ini sebanyak 60 subjek yang terdiri dari 30 anak usia $2-6$ tahun yang dititipkan di TPA dan 30 anak usia 2 - 6 tahun yang tidak dititipkan di TPA. Teknik pengambilan sampel yang digunakan dalam penelitian ini adalah Sampling Purposive. Alat ukur yang digunakan dalam penelitian ini adalah Vineland Social Maturity Scale (VSMS). Penelitian ini di analisa dengan menggunakan uji T (t-test) dan diperoleh nilai uji-t sebesar 10,037 dan menunjukkan bahwa signifikansi yang diperoleh 0,000 $(\mathrm{p}<0,001)$. Hasil ini berarti ada perbedaan yang signifikan antara kematangan sosial anak yang dititipkan dan yang tidak dititipkan di taman penitipan anak (TPA). Sebagian besar anak yang dititipkan di TPA tergolong dalam kategori kematangan sosial yang tinggi dengan rerata 108,3, sedangkan sebagian besar anak yang tidak dititipkan di TPA berada pada kategori kematangan sosial yang cukup dengan rerata 82,18.
\end{abstract}

Kata Kunci : Kematangan sosial, Anak Usia Dini, Taman Penitipan Anak (TPA) 


\section{LATAR BELAKANG}

$\mathrm{U}$

sia dini merupakan periode emas (golden age) bagi perkembangan anak untuk memperoleh proses pendidikan. Periode ini adalah tahun - tahun berharga bagi seorang anak untuk mengenali berbagai macam fakta di lingkungannya sebagai stimulans terhadap perkembangan kepribadian, psikomotor, kognitif maupun sosialnya (Mutiah, 2010). Pengertian anak usia dini sendiri menurut Undang-Undang Sistem Pendidikan Nasional No. 20 tahun 2003 pasal 28 ayat 1 yaitu "anak usia dini adalah anak yang masuk dalam rentangan usia 0 6 tahun". Pada masa ini terdapat beberapa anak di sekitar kita yang mengalami hambatan kematangan sosial, yaitu anak berusia 3 tahun yang belum mampu buang air kecil di toilet. Individu yang belum mampu menyelesaikan tugas perkembangannya akan mengalami kegagalan pada tugas perkembangan selanjutnya (Havighurst dalam Berns, 2010). Mengacu pada pendapat Havighurst, maka individu harus mempelajari hal-hal yang berkaitan dengan kematangan sosial agar tidak mengalami hambatan kematangan sosial.

Kematangan sosial merupakan kemampuan individu untuk mengurus dirinya dan berpartisipasi atau ikut serta dalam kegiatan yang mengarahkan pada kemandirian (Doll dalam Sinata, 2003). Lebih lanjut Doll menyebutkan ada beberapa aspek kematangan sosial anak usia dini yaitu (a) Menolong diri sendiri secara umum (self-help general), seperti mencuci muka, mencuci tangan tanpa bantuan, pergi tidur sendiri, Kemampuan ketika makan (self eating), seperti mengambil makanan sendiri, menggunakan garpu, memotong makanan lunak, (c) Kemampuan berpakaian (selpdressing), seperti menutup kancing baju, berpakaian sendiri tanpa bantuan, (d) Mengarahkan pada diri sendiri (selfdirection), seperti mengatur uang atau dapat dipercaya dengan uang dan dapat mengatur waktu, (e) Gerak (locomotion), seperti menuruni tangga dengan menginjak satu kali tiap anak tangga, pergi ke tetangga dekat tanpa di awasi, pergi sekolah tanpa di antar, (f) Pekerjaan (occupation), seperti 
membantu pekerjaan rumah tangga yang ringan, menggunakan pensil dan menggunakan pisau, (g) Sosialisasi (sosialization), seperti bersama temantemannya, mengikuti suatu permanianan, mengikuti lomba, (h) Komunikasi (communication), seperti berbicara dengan orang yang ada disekitarnya, menulis kata sederhana. Dengan kematangan sosial yang dimiliki akan mempermudah anak untuk berorientasi dan bersosialisasi pada dunia luar yaitu lingkungan masyarakat. Selain itu juga akan mempermudah dalam melakukan hubungan sosial secara mandiri, maksudnya seseorang tidak akan berkembang menjadi individu yang tergantung pada lingkungan sosialnya (Wulandari, 2009).

Kematangan sosial pada tiap individu sangat beragam dan hal ini disebabkan adanya interaksi antara faktor internal (nuture), yaitu kematangan biologis individu dan faktor eksternal (nurture), yaitu orang-orang di sekitar individu. Faktor eksternal bagi anak-anak usia prasekolah adalah keluarga (Yusuf, 2008). Seiring berjalannya waktu dan berkembangnya jaman, terjadilah perubahan sosial yang menuntut para ibu untuk bekerja membantu kebutuhan financial keluarga. Dampaknya, ibu harus menduduki peran dalam pekerjaan dan keluarga secara bersamaan (Stewart \& Platt dalam Goldenberg \& Goldenberg, 1985), sehingga ibu bekerja menggunakan beberapa cara lain untuk mengurus anaknya, seperti menitipkannya kepada Orang Tua (Grandparents), pembantu rumah tangga, atau menitipkannya di Taman Penitipan Anak (TPA).

Taman Penitipan Anak adalah salah satu bentuk layanan PAUD (Pendidikan Anak Usia Dini) yang menyelenggarakan program pendidikan sekaligus pengasuhan dan kesejahteraan sosial terhadap anak sejak lahir sampai dengan usia enam tahun. Pelayanan pendidikan yang berfungsi sebagai pengganti peran keluarga, seperti orangtua yang mulai sibuk bekerja atau karena keperluan lainnya (Petunjuk Teknis Penyelenggaraan TPA, 2012). Penyelenggaraan pendidikan usia dini, termasuk di Taman Penitipan Anak, minimal harus berpedoman pada "Tempa, Asah, Asih, Asuh". Tempa diartikan sebagai 
latihan yang dilakukan berulang-ulang. Hal ini sesuai dengan kerja otak, dimana synape-synape otak anak semakin kuat dan dan bersifat menetap. Asah dimaksudkan agar anak usia dini memiliki kondisi intelektual yang berkembang, sehat, dan berkualitas. Asih pada dasarnya merupakan pendamping dan perlindungan anak usia dini, sebagai upaya mewujudkan dan menjamin pemenuhan kebutuhan anak, hak kelangsungan hidup, emansipasi, hak tumbuh kembang, hak pemdapat perlindungan dari pengaruh kekerasan dan segala bentuk eksploitasi, serta hak untuk berpartisipasi secara penuh, termasuk pemanfaatan waktu luang. Asuh mengandung arti menjaga dan membimbing anak agar dapat mandiri. Menjaga dan membimbing anak tidak dapat dilepaskan dari proses mendidik anak agar mereka memiliki kemampuan sesuai dengan potensi mereka (Petunjuk Teknis Penyelenggaraan Taman Penitipan Anak, 2012).

Berdasarkan observasi yang dilakukan pada anak usia 4-5 tahun di TK X di Ungaran, diketahui bahwa anak-anak yang sebelumnya berada di TPA dapat memasang sepatunya sendiri dan dapat membuka celananya sendiri saat ingin buang air kecil, sedangkan anak-anak yang sebelumnya tidak berada di TPA cenderung berada di samping orang tua dan masih cenderung meminta bantuan guru, sementara seharusnya pada usia 4 tahun anak sudah mampu menyelesaikan tugastugas yang sederhana seperti yang disebutkan di atas. Sejalan dengan hal tersebut, penelitian Wulandari (2009) menemukan hasil bahwa terdapat perbedaan yang signifikan antara tingkat kematangan sosial anak yang mengikuti playgroup dengan anak yang tidak mengikuti playgroup. Hasil dari penelitian tersebut adalah tingkat kematangan sosial anak yang mengikuti playgroup lebih tinggi daripada anak yang tidak mengikuti playgroup. Hasil berbeda ditemukan dalam penelitian yang dilakukan oleh NICHD Early Child Care Reaserch Network (dalam Papalia, dkk, 2008), bahwa terdapat berbagai faktor yang terkait dengan pengasuhan anak yang dapat dengan kuat memprediksi hasil perkembangan, terlepas 
dari seberapa banyak waktu yang dihabiskan anak di tempat penitipan anak.

Perbedaan hasil penelitian tersebut membuat peneliti tertarik untuk melakukan penelitian dengan tujuan melihat perbedaan kematangan sosial anak usia dini ditinjau dari keikutsertaan di Taman Penitipan Anak (TPA). Hipotesis yang diajukan adalah ada perbedaan signifikan kematangan sosial anak usia dini ditinjau dari keikutsertaan di taman penitipan anak.

\section{METODE PENELITIAN}

\section{Variabel Penelitian}

Variabel tergantung : kematangan sosial anak usia dini

Variabel bebas : keikutsertaan di Taman Penitipan Anak (TPA), yaitu (1) ikut serta dalam TPA, dan (2) tidak ikut serta dalam TPA.

\section{Populasi dan Sampel Penelitian}

Populasi dalam penelitian ini adalah anak yang berusia $2-6$ tahun yang dititipkan di TPA dan tidak, di kota Ungaran. Teknik yang digunakan adalah
Purposive Sampling, dengan karakteristik sampel dalam penelitian ini adalah sebagai berikut :

a. Subjek merupakan anak usia 2- 6 tahun

b. Berjenis kelamin laki-laki dan perempuan

c. Subjek yang di titipkan di Taman Penitipan Anak (TPA) dan subjek yang tidak di titipkan di TPA.

d. Subjek di titipkan di TPA minimal 7 bulan.

e. Subjek yang tidak dititipkan di TPA diasuh oleh kakek, nenek, kerabat, atau pembantu rumah tangga.

\section{Pengumpulan Data}

Pengumpulan data dilakukan dengan menggunakan skala Vineland Sosial Maturity Scale (VSMS) yang dikembangkan oleh Doll. Skor daya beda item VSMS bergerak dari 0,31 sampai dengan 0,54 yang ditentukan terutama dari perbedaan usia, perbandingan antara subjek normal dengan subjek yang memiliki latar belakang retardasi mental, dan korelasi skor yang diperoleh dari penilaian observer yang 
mengetahui dengan baik bagaimana perilaku subjek sesungguhnya. Reliabilitas sebesar 0,90 yang dilakukan dengan teknik tes-retes, dalam jangka waktu antara satu hari sampai dengan sembilan bulan.

VSMS merupakan salah satu tes yang didalamnya terdapat 117 item pertanyaan perintah, namun tidak semua item di berikan melainkan disesuaikan dengan usia kronologis anak. Pengambilan data dilakukan oleh peneliti untuk menghindari penilaian subjektif dari orangtua. Penilaian dalam alat ukur VSMS yaitu jika anak dapat melakukan apa yang tertulis pada angket akan dinilai + (plus) $=$ 1, jika anak kadang-kadang bisa melakukan apa yang tertulis pada angket akan dinilai $+/-($ plusminus $)=1 / 2$, dan jika anak belum bisa melakukan apa yang tertulis pada angket akan dinilai - (minus) $=0$. Aspek yang digunakan untuk mengungkap kematangan sosial pada anak usia dini yaitu:

a. Menolong diri sendiri secara umum (self-help general) b. Kemampuan ketika makan (self eating)

c. Kemampuan berpakaian (selpdressing)

d. Mengarahkan pada diri sendiri (selfdirection)

e. Gerak (locomotion)

f. Pekerjaan (occupation)

g. Sosialisasi (sosialization)

h. Komunikasi (communication)

Semakin tinggi usia mental anak maka semakin baik kematangan sosial anak.

Penelitian ini dilakukan dengan jumlah subjek 60 anak yang terdiri dari 30 anak yang dititipkan di TPA dan 30 anak yang tidak dititipkan di TPA melainkan anak yang di asuh oleh pembantu rumah tangga, kakek/nenek, atau kerabat.

\section{Teknik Analisis Data}

Data dianalisa dengan uji t (t-test) untuk mengetahui perbedaan kematangan sosial anak yang mengikuti TPA dan yang tidak.

\section{HASIL PENELITIAN}

\section{Statistik Deskriptif}


Hasil analisis deskriptif pada tabel 1 menunjukkan kematangan anak usia dini yang dititipkan di TPA cenderung berada pada kategori baik dengan nilai rata-rata
108,3, sedangkan kematangan anak usia dini yang tidak dititipkan di TPA cenderung berada pada kategori cukup dengan nilai rata-rata 82,18 .

Tabel 1

Kategorisasi Kematangan Sosial Anak Usia Dini yang Dititipkan di TPA

\begin{tabular}{|c|c|c|c|c|c|c|c|c|}
\hline \multicolumn{6}{|c|}{ TPA } & \multicolumn{3}{|c|}{ Non TPA } \\
\hline No & Interval & Kategorisasi & Mean & $\mathbf{F}$ & $\%$ & Mean & $\mathbf{F}$ & $\%$ \\
\hline 1. & $0 \leq x<47$ & Kurang Baik & & 0 & $0 \%$ & & 0 & $0 \%$ \\
\hline 2. & $48 \leq x<94$ & Cukup & & 3 & $10 \%$ & 82.18 & 28 & $93,33 \%$ \\
\hline 3 & $94 \leq x<140$ & Baik & 108,3 & 27 & $90 \%$ & & 2 & $6,67 \%$ \\
\hline \multicolumn{4}{|c|}{ Jumlah } & 30 & $100 \%$ & & 30 & $100 \%$ \\
\hline
\end{tabular}

$\mathrm{X}=$ skor kematangan sosial

Uji Asumsi

Uji normalitas sebaran data dari variabel kematangan sosial anak dilakukan dengan menggunakan Kolmogorov-Smirnov test. Berdasarkan hasil uji normalitas diperoleh nilai $K S-Z$ untuk sampel TPA sebesar 0,686 (p>0,05), sedangkan nilai $K S$ $Z$ untuk sampel Non TPA sebesar 0,276 $(0>0,05)$. Berdasarkan hasil tersebut dapat dilihat bahwa data berdistribusi normal.

Uji homogenitas dilakukan dengan menggunakan Levene's Test. Berdasarkan perhitungan diperoleh nilai Levene's dengan $\mathrm{p}$ value (sig) sebesar $0,937(\mathrm{p}>0,05)$ yang berarti terdapat kesamaan varians antar kelompok atau yang berarti homogen.

\section{Uji Beda}

Pengujian perbedaan dilakukan dengan uji $\mathrm{t}$ menggunakan Independent Sample t-test yang digunakan untuk mengetahui ada atau tidaknya perbedaan rata-rata antara dua kelompok sampel yang tidak berhubungan. Berdasarkan hasil perhitungan diperoleh nilai $t$ sebesar 10,037 dengan $\mathrm{p}=0,000(\mathrm{p}<0,001)$. Dengan demikian maka H0 ditolak, dan H1 diterima, 
yang artinya ada perbedaan kematangan

sosial anak usia dini ditinjau dari keikutsertaan di Taman Penitipan Anak (TPA).

Tabel 2

Uji Independen T Test

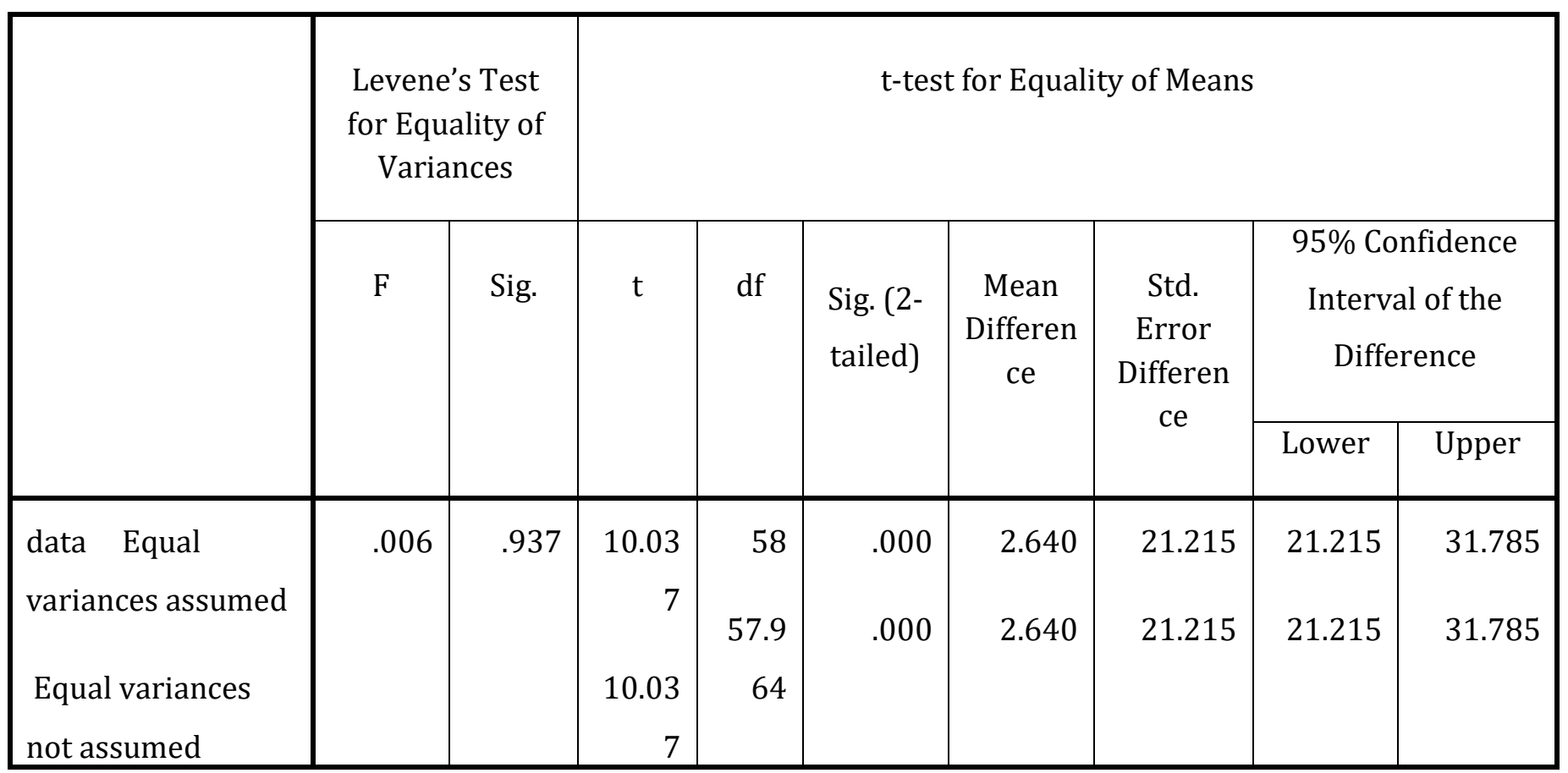

PEMBAHASAN

Berdasarkan hasil analisis menggunakan t-test diperoleh nilai $\mathrm{t}$ sebesar 10,037 ( $p=0,000 ; p<0,001)$. Ini berarti bahwa ada perbedaan yang signifikan antara kematangan sosial anak yang dititipkan dan yang tidak dititipkan di taman penitipan anak (TPA). Kematangan sosial anak yang dititipkan di TPA lebih baik dibandingkan anak yang tidak dititipkan di TPA.

Berdasarkan hasil penelitian yang dilakukan oleh Peth-Pierce (dalam Papalia, dkk, 2008), terlihat bahwa anak yang dititipkan di TPA akan dapat belajar lebih cepat untuk mengembangkan kemampuan, terutama dalam beradaptasi dengan lingkungan dan juga mencapai kematangan sosial. Semakin dini usia anak ketika 
menerima pengalaman-pengalamannya, akan semakin baik pula kemampuannya. Sebab tidak dapat dipungkiri bahwa latihan serta pengalaman dapat membantu proses perkembangan anak (Hurlock, 2000). Proses perkembangan anak akan berjalan dengan baik apabila selain memperoleh rangsangan untuk bereksplorasi, anak juga berinteraksi dengan teman-teman sebayanya (Murti, 2006). Dalam hal ini, TPA menjadi salah satu pilihan untuk memenuhinya.

TPA menyelenggarakan program pendidikan sekaligus pengasuhan sehingga anak yang berada di TPA akan mendapatkan pendidikan setara dengan pendidikan anak usia dini (PAUD) yang membantunya untuk mengembangkan kematangan sosial, sementara anak yang tidak berada di TPA kurang optimal dalam pencapaian kematangan sosial. Hal tersebut disebabkan proses pembelajaran yang diterapkan oleh pengasuh terhadap anak tidak memiliki standar acuan untuk mengembangkan kemampuankemampuannya, sehingga anak mendapat stimulasi yang terbatas hanya dalam lingkungan terdekat seperti anggota keluarga. Pendapat tersebut diperkuat oleh Hurlock (2000), yang menyatakan bahwa anak yang mengikuti pendidikan prasekolah melakukan penyesuaian sosial yang lebih dibandingkan dengan anak-anak yang tidak mengikuti pendidikan prasekolah.

Selama penelitian berlangsung anak yang berada di TPA akan mendapatkan pembiasaan-pembiasaan yang mendukung anak menuju kematangan sosial. Seperti halnya setelah minum susu (menggunakan dot) anak dibiasakan untuk menaruh dotnya di meja yang sudah disediakan. Khususnya bagi anak-anak yang sudah berusia di atas 2 tahun keatas, anak akan dibiasakan untuk makan sendiri hal ini juga melatih motorik pada anak. Lain halnya untuk anak-anak yang tidak berada di TPA melainkan diasuh oleh nenek, pembantu rumah tangga, atau kerabat dekat akan cenderung dibantu. Frekuensi dan intensitas bantuan yang diberikan tersebut akan membuat terhambatnya kematangan sosial anak, sehingga saat anak masuk ke dunia pendidikan mereka akan cenderung 
meminta bantuan atau belum mandiri, hal ini menunjukkan kurangnya kematangan sosial (Wulandari, 2009). Doll (dalam Habibi, 2003) juga menyatakan bahwa kematangan sosial akan nampak pada perilaku anak, dan perilaku tersebut menunjukkan kemampuan dalam mengurus diri dan partisipasi dalam aktivitas-aktivitas yang mengarah pada kemandirian layaknya orang dewasa. Dengan demikian, kematangan sosial merupakan kemampuan dan keterampilan yang penting bagi anak, dan dapat distimulasi perkembangannya melalui keikutsertaan dalam TPA.

\section{Kesimpulan}

Berdasarkan hasil penelitian diketahui bahwa ada perbedaan yang signifikan kematangan sosial anak usia dini yang ikut serta dan yang tidak ikut serta dalam Taman Penitipan Anak (TPA). Kematangan sosial anak yang ikut serta dalam TPA lebih tinggi dari anak yang tidak ikut serta dalam TPA, dengan rerata kematangan sosial anak yang dititipkan di TPA sebesar 108,3 (kategori tinggi) sedangkan rerata kematangan sosial anak yang tidak dititipkan di TPA sebesar 82,18 (kategori cukup).

\section{Saran}

1. Bagi Orangtua

Diharapkan orangtua yang bekerja dapat memahami dan menerapkan halhal yang dapat mendukung kematangan sosial anak sehingga anak dapat mencapai kematangan sosial secara optimal. Bagi Orangtua yang anaknya berada di Taman Penitipan Anak (TPA) tetap memilah-milah Tempat Penitipan Anak yang terpercaya dan sesuai dengan pendidikan yang baik bagi anak. Lalu lebih memperperkuat pemahaman dan kesadaran orangtua akan pentingnya pendidikan anak usia dini. Bagi Orangtua yang tidak menitipkan anaknya di TPA sebaiknya tetap memberikan pembiasaan yang mendorong kematangan sosial anak atau mengikutsertakan anak di Lembaga Pendidikan Anak Usia Dini (PAUD). 
2. Bagi Pengelola Taman Penitipan Anak (TPA)

Diharapkan bagi pengelola TPA tetap profesional dalam memberikan pembiasaan pada anak dan menambah aspek yang ada pada kematangan sosial sehingga anak tidak hanya cenderung pada satu atau dua aspek saja. Pengelolaan TPA harus tetap sesuai dengan Pedoman Taman Penitipan Anak yang telah digariskan oleh Direktorat Pendidikan Anak Usia Dini. Kemudian pula rekruitas tenaga pengasuh lebih selektif lagi sehingga tidak ada kecerobohan yang dilakukan oleh pengasuh.

3. Bagi peneliti selanjutnya

Diharapkan dapat mengembangkan dengan variabel lain yang mempengaruhi seperti kematangan emosional dan bahasa atau memberikan faktor-faktor yang dapat mempengaruhi kematangan sosial anak seperti : jenis kelamin, urutan kelahiran, status sosial, dan urutan kelahiran anak.

\section{DAFTAR PUSTAKA}

Ariyanti, P.D. (2009). Hubungan Antara Persepsi Terhadap Metode Pendidikan Alternatif Berbasis Komunitas dengan Kemandirian Siswa di Sekolah Qoryah Toyyibah Salatiga. Skripsi. (tidak diterbitkan) Surakarta: Fakultas Psikologi UMS.

Astuti, M.S. 2005. Hubungan Antara Intensitas Permainan Kooperatif Dengan Kematangan Sosial Pada Anak Prasekolah. Skripsi. (tidak diterbitkan). Surakarta : Fakultas Psikologi Universitas Muhammadiyah Surakarta.

Depsos. 2002. Pedoman Penyelenggaraan Pelayanan Sosial Anak di Taman Penitipan Anak (TPA). Jakarta: Ditjen Bina Kesejahteraan Sosial Depsos RI.

Desiyanty, S. 2015. Pelayanan Pendidikan Taman Penitipan Anak dalam Pengasuhan Anak di TPA LKIA Pontianak. Tesis. Jurnal Tesis PMISUNTAN-PSS-2015.

Direktorat PAUD. 2006. Pedoman Teknis Penyeleggaraan Kelompok Bermain. Jakarta: Direktorat PAUD-Dirjen PLSP-Depdiknas.

Doll, F.A. (1965). Vineland Sosial Maturity Scale. American Guidance Service. Condensed Manual of Direction Minnesota.

Goldenberg, I., \& Goldenberg, H. 1985. Family therapy: An overview (2nd ed). Belmot, California: Wadsworth, Inc.

Hartono, B. (1997). Melatih Anak Percaya Diri. Jakarta: PT BPK Gunung Mulia

Hurlock, E.B. 1999. Psikologi Perkembangan: Suatu Pendekatan Sepanjang Rentang Kehidupan. Jakarta: Penerbit Erlangga.

Irawati, D. 2002. Hubungan Antara Penerimaan Teman Sebaya dengan Kematangan Sosial pada Remaja. http://digital.lib.itb.ac.id/gdl.php?mod =browse\&op=read\&id=jiptumm-gdl-sl- 
2002-devy-8676-remaja\&q=Sosial diakses pada tanggal 14 Mei 2016

Kartono, K. 1995. Psikologi Anak (Psikologi Perkembangan). Medan: Penerbit Universitas Sumatera Utara.

Mutiah, D. 2010. Psikologi Bermain Anak Usia Dini. Jakarta: Kencana

Murti, H.A.S. 2006. Perilaku Adaptif Anak Dalam Playgroup. Anima Indonesian Psychological Journal 22(1), 86 - 91.

Papalia D.E., Old S.W., Feldman R.D.,2008, Human Development (Psikologi Perkembangan), Jakarta: Kencana Prenada Media Group.

Petunjuk Teknis Penyelenggaraan Taman Kanak-Kanak. Direktor Pembinaan Pendidikan Anak Usia Dini. 2011.

Petunjuk Teknis Penyelenggaraan Taman Penitipan Anak. Pemerintah Provinsi Jawa Tengah Dinas Pendidikan. 2012.

Rahmawati, R.R. 2013. Perbedaan Tingkat Kemandirian Anak Taman KanakKanak Kelompok A Antara yang Mengikuti Playgroup dan Tidak di TK Aisyiyah Bustanul Athfal 3 Surabaya. Calyptra: Jurnal Ilmiah Mahasiswa Universitas Surabaya 2 (2).
Singgih, G.J 2013. Perbedaan Kematangan Sosial Anak Usia Prasekolah di Taman Penitipan Anak (TPA) X dan Y. Calyptra: Jurnal Ilmiah Mahasiswa Universitas Surabaya 2(1).

Sugiyono. 2011. Metode Penelitian Kuantitatif, Kualitatif, dan $R$ \& D. Bandung: CV. ALFABETA.

Sugiyono. 2012. Metode Penelitian Kombinasi (Mixed Methods). Bandung: CV. ALFABETA.

Suwarsiyah, A. 1999. Menumbuhkan Kemandirian Anak, Kreativitas dan Konsep Diri yang Sehat Anak Usia Dini. Yogyakarta: UII.

Wahyuti, T. 2003. Posisi Strategi Taman Penitipan Anak.

Wijaya, W. 2004. Kamus Lengkap InggrisIndonesia. Semarang : Bintang Jaya.

Wulandari, A. 2009. Perbedaan Kematangan Sosial Anak Ditinjau dari Keikutsertaan Pendidikan Prasekolah (Playgroup). Skripsi. (tidak diterbitkan) Surakarta: Fakultas Psikologi UMS.

Yusuf, S. 2008. Psikologi Perkembangan Anak dan Remaja. Bandung : PT. Remaja, Rosdakarya. 